\title{
FAKTOR-FAKTOR YANG MEMPENGARUHI FUNGSI KOGNITIF PADA PASIEN DIABETES MELITUS TIPE 2
}

\author{
Yaumi Faiza, Yuliarni Syafrita \\ ${ }^{1}$ Fakultas Kedokteran, Universitas Andalas, Jl. Perintis Kemerdekaan No14D, Sawahan Timur, Padang \\ email: faizayaumi @gmail.com \\ ${ }^{2}$ Fak ultas Kedok teran, Universitas Andalas, Jl.Perintis Kemerdekaan No14D, Sawahan Timur, Padang \\ email: ysyafrita@yahoo.com
}

Submitted : 13-02-2020, Reviewer:15-02-2020, Accepted: 16-02-2020

\begin{abstract}
Background :The number of Dementia is increasing year by year, and it will be 3.980 .000 in 2050 In Indonesia, as well as the world. Dementia can be triggered by Diabetes Mellitus type 2. Long hyperglycemia can induce beta amiloid in brain, that declines the cognitive function. Besides, some factors can influence cognitive function such as age, sex, level of education and duration of DM type 2. The aim of this study is to review the faktors that influence cognitive function of DM type 2.Methods: The study design was cross sectional, with 56 subjects. The collective data were age, sex, level of education, duration of DM type 2, and cognitive function which is determined by using MoCA Ina The variables associated were tested by using Chi-Square Test, and the association is significant if $p<0,05$.

Results: From 56 research subjects, 32 (57,14\%) subjects are female, high level of education is 76,79\%, and 57,14\% subjects are suffering from DM for 5-<10 years. The average MoCA Ina value was $23+$ 3.47. There are $37(66.1 \%)$ subjects with cognitive decline. There is no significant associations between age, sex, level of education, duration of DM and cognitive function ( $p>0,05)$.
\end{abstract}

Keywords: cognitive function, DM type 2

\begin{abstract}
Abstrak
Latar Belakang : Jumlah Orang Dengan Demensia (ODD) diperkirakan akan makin meningkat dari tahun ke tahun, dimana diperkirakan 3.980.000 penderita ODD di tahun 2050 di Indonesia. Demensia dapat dipicu oleh diabetes melitus tipe 2 (DM tipe2). Hiperglikemia yang berulang dan lama, dapat meningkatkan proses pembentukan beta amiloid di otak, yang dapat mengganggu fungsi kognitif. Selain itu, beberapa faktor dapat mempengaruhi terjadinya gangguan kognitif, seperti umur, jenis kelamin, tingkat pendidikan, dan lama menderita DM. Tujuan penelitian ini adalah untuk melihat faktor-faktor yang berhubungan dengan fungsi kognitif pada pasien DM tipe 2.

Metode Penelitian : Disain penelitian adalah cross sectional, dengan jumlah subjek 56 orang. Data yang dikumpulkan adalah umur, jenis kelamin, tingkat pendidikan, lama menderita DM tipe 2, dan fungsi kognitif dengan MoCA Ina. Hubungan variabel diuji dengan Chi-Square test, bermakna bila $\mathrm{p}<0,05$. Hasil : Dari 56 subjek penelitian,didapatkan perempuan 32 (57,14\%) subjek, pendidikan tinggi (76,79\%), sebanyak 57,14\% subjek menderita DM selama 5-<10 tahun. Rerata nilai MoCA Ina adalah $23 \pm 3.47$, dan terdapat $37(66.1 \%)$ subjek mengalami gangguan kognitif. Tidak terdapat hubungan yang bermakna antara jenis kelamin, tingkat pendidikan dan lama menderita DM dan umur $(\mathrm{p}>0,05)$.
\end{abstract}

Kata kunci : fungsi kognitif, DM tipe 2 


\section{PENDAHULUAN}

Proses degenerasi otak yang menyertai penuaan otak akan menimbulkan banyak masalah kesehatan, termasuk penyakit degeneratif yang berdampak terhadap penurunan fungsi kognitif. Penurunan fungsi kognitif akan mengganggu aktivitas sehari-hari bila sudah berlanjut menjadi demensia (Ramli ,2017).

Perawatan demensia sendiri merupakan beban berat yang berdampak bagi sosial dan ekonomi bagi keluarga.Otak yang tidak produktif tidak saja mengakibatkan timbulnya masalah kesehatan dan masalah sosial tetapi juga menjadi beban ekonomi. Beban biaya yang harus ditanggung untuk orang dengan demensia yang dikeluarkan oleh negara-negara berpenghasilan menengah keatas, diperkirakan mencapai US\$ 32,5 Milliar atau 325 Triliun rupiah per tahun (World Report Alzheimer, 2012).

Di Indonesia, jumlah Orang Dengan Demensia (ODD) diperkirakan akan makin meningkat dari 960.000 di tahun 2013, menjadi 1.890 .000 di tahun 2030 dan 3.980.000 ODD di tahun 2050 (World Report Alzheimer, 2012). Seperti pada Alzheimer Disease (AD), prevalensi Vascular Demensia (VaD) meningkat seiring pertambahan usia, dengan kisaran $1,5 \%$ sampai $4,8 \%$ pada usia 70 -an tahun. Terdapat banyak estimasi yang berbeda, yang jelas semua demensia merupakan masalah kesehatan utama dengan peningkatan secara eksponensial pada usia diatas 65 tahun (Black, 2011). Seiring meningkatnya harapan hidup, angka penderita demensia diprediksikan meningkat dari 24,3 juta pada tahun 2001 menjadi 81,1 juta pada tahun 2040 di seluruh dunia (Duron et al., 2008).

Beberapa faktor yang dapat memicu terjadinya gangguan kognitif, salah satunya adalah Diabetes Melitus tipe 2 (DM tipe 2). DM tipe 2 merupakan gangguan metabolik dengan etiologi beragam yang memiliki karakteristik peningkatan kadar glukosa darah akibat kombinasi resistensi insulin dan sekresi insulin yang inadekuat (Kasper DL et al, 2015). DM tipe 2 merupakan tipe diabetes yang paling banyak diderita, meliputi $90 \%$ dari keseluruhan diabetes (Shahet al,2015). Saat ini terdapat kecenderungan peningkatan jumlah penderita DM tipe 2, dimana terdapat sekitar 382 juta orang penderita DM tipe 2 di seluruh dunia dan diperkirakan akan mencapai 600 juta penderita pada tahun 2035. Peningkatan penderita DM tipe 2 tertinggi terdapat di kawasan Asia Tenggara dengan proyeksi penderita di Indonesia akan mencapai 21,3juta orang di tahun 2030 (Unwin, 2011).

Pada DM tipe 2, terjadi hiperglikemia yang lama, yang menyebabkan end organ damage, termasuk microvascular disease, yang ditandai dengan degenerasi otak difus, demielinisasi pada sistem saraf dan terjadinya fibrosis saraf. Hal ini ditandai dengan adanya apaptosis dan atrofi hipokampus. Sehingga terjadi penurunan fungsi kognitif pada pasien DM tipe 2 (Kodl,2008). Faktor lain yang juga mempengaruhi fungsi kognitif seperti jenis kelamin, umur, dan tingkat pendidikan (Ferrari,2018).

\section{METODE PENELITIAN}

Disa in penelitian ini adalah cross sectional. Pasien yang memenuhi kriteria inklusi dan eksklusi dilakukan pemeriksaan fungsi kognitif saat pasien datang kontrol ke poli endokrin RS M Djamil Padang dan RS Ibnu Sina Padang. Pengumpulan sampel penelitian dilakukan sejak bulan Juni 2019 sampai Oktober 2019. Data yang dikumpulkan adalah umur, jenis kelamin, lama menderita DM, tingkat pendidikan, dan pemeriksaan MoCA Ina untuk menilai fungsi kognitif. Nilai normal MoCA Ina adalah 26-30. Hubungan antar variabel diuji dengan Chi-Square, bermakna jika $\mathrm{p}<0,05$. 


\section{HASIL DAN PEMBAHASAN}

Subjek penelitian berjumlah 56 orang. Berdasarkan jenis kelamin, didapatkan perempuan 32 (57.14\%) subjek dan laki-laki 24 (42.86\%). Berdasarkan tingkat pendidikan, subjek penelitian didominasi oleh pendidikan tinggi (76.79\%). Berdasarkan lama menderita DM tipe 2, sebagian besar $(57.14 \%)$ subjek menderita DM selama 5-<10 tahun. Sebanyak 31 $(55,4 \%)$ subjek dengan umur $\geq 60$ tahun. Rerata nilai MoCA Ina adalah $23 \pm 3.47$. Sebagian besar $(66.1 \%)$ subjek dengan nilai MoCA Ina terganggu.

Tabel 1. Distribusi Karakteristik Umum Subjek Penelitian

\begin{tabular}{lcc}
\hline Karakteristik & $\begin{array}{c}\text { Frekuensi } \\
\text { (n) }\end{array}$ & $\begin{array}{c}\text { Persentase } \\
(\%)\end{array}$ \\
\hline JenisKelamin & & \\
Laki-laki & 24 & 42,86 \\
Perempuan & 32 & 57,14 \\
Pendidikan & & \\
Rendah & 13 & 23,21 \\
Tinggi & 43 & 76,79 \\
& & \\
Lama & & \\
Menderita DM & & \\
(tahun) & & \\
5-<10 & 32 & 57,14 \\
$\geq 10$ & 24 & 42,86 \\
$\quad$ Median & & \\
$\quad($ min-max $)=$ & & \\
$\quad 8$ (5-30) & & \\
Umur (th) & & \\
$40-<60$ & 25 & 44,6 \\
$\geq 60$ & 31 & 55,4 \\
\hline
\end{tabular}

Dari 56 subjek penelitian dengan DM tipe 2, lebih dari setengah subjek $(57.14 \%)$ berjenis kelamin perempuan. Hal serupa juga dinyatakan oleh Dongwha bahwa prevalensi perempuan lebih tinggi dibandingkan dengan laki-laki untuk terjadinya gangguan kognitif. Hal ini dikaitkan dengan genetik yang berdampak lebih besar pada proses patologi amiloid, dan hormon sex (Dongwha, 2018).

Tingkat pendidikan juga telah dipelajari hubungannya dengan fungsi kognitif. Pada penelitian ini didapatkan sebagian besar subjek berpendidikan tinggi (yaitu 76,79\%). Hasil yang sama juga didapatkan pada penelitian Alina Flatz tahun 2015 yang menjelaskan bahwa pasien dengan tingkat edukasi lebih tinggi mempunyai kesadaran lebih tinggi untuk melakukan kontrol teratur, sehingga lebih banyak koresponden dengan tingkat edukasi lebih tinggi yang terjaring (Flatz, 2015).

Tabel 2. Hubungan faktor karakteristik dasar dengan fungsi kognitif.

\begin{tabular}{|c|c|c|c|c|}
\hline $\begin{array}{l}\text { Karakteristik } \\
\text { dasar }\end{array}$ & $\begin{array}{l}\text { Fungsi kog } \\
\text { Terganggu } \\
\text { (n) }\end{array}$ & $\begin{array}{l}\text { Tif } \\
\text { Tidak } \\
\text { tergangg } \\
\mathrm{u}(\mathrm{n})\end{array}$ & $\mathrm{p}$ & OR \\
\hline JenisKelamin & & & & \\
\hline $\begin{array}{l}\text { Perempuan } \\
\text { Laki-laki }\end{array}$ & $\begin{array}{l}19 \\
18\end{array}$ & $\begin{array}{l}13 \\
6\end{array}$ & 0,26 & 2,05 \\
\hline Tingkat & & & & \\
\hline $\begin{array}{l}\text { Pendidikan } \\
\text { Rendah } \\
\text { Tinggi }\end{array}$ & $\begin{array}{l}6 \\
31\end{array}$ & $\begin{array}{l}7 \\
12\end{array}$ & 0,08 & 0,33 \\
\hline $\begin{array}{c}\text { Lama DM } \\
\quad>10 \\
5-<10\end{array}$ & $\begin{array}{l}16 \\
21\end{array}$ & $\begin{array}{l}8 \\
11\end{array}$ & 0,93 & 1,04 \\
\hline $\begin{array}{l}\text { Umur } \\
40-<60 \\
>60\end{array}$ & $\begin{array}{l}22 \\
15\end{array}$ & $\begin{array}{l}10 \\
9\end{array}$ & 0,62 & 1,32 \\
\hline
\end{tabular}

Pertambahan usia dapat menyebabkan menurunnya fungsi kognitif. Degenerasi otak menyebabkan penurunan volume gray matter di kortex prefrontal, dan volume white matter di lobus frontal dan korpus kalosum yang berdampak pada kognisi (Danie1,2015). Pada penelitian ini, terdapat umur > 60 tahun 55,4\% subjek. Tabel 2 memperlihatkan tidak terdapatnya hubungan yang bermakna antara ; umur (p 0,62; OR 1,32), jenis kelamin ( 0 ,26; OR 2,05), tingkat pendidikan (p 0,08; OR 0,33) dan lamanya menderita DM $(p=0,93, O R \quad 1,04)$ terhadap fungsi kognitif.

Nilai normal MoCA Ina adalah 26-30. Rerata nilai MoCA Ina pada 56 subjek penelitian ini adalah $23 \pm 3,47$. Penelitian yang dilakukan Tuba tahun 2014 yang menyebutkan terdapat rerata nilai MoCA Ina pada pasien DM tipe 2 adalah 
15,53 $\pm 6,18$. Penurunan Nilai MoCA Ina pada DM tipe 2 disebabkan oleh penurunan volume gray matter otak yang terjadi pada kondisi hiperglikemia yang lama. Selain itu hiperglikemia juga menyebabkan produksi superoksida oleh mitokondria yang secara langsung akan menyebabkan toksik pada otak dan memicu disfungsi neuron dan kematian sel, dan secara tidak langsung menyebabkan perubahan mikrovaskular dan makrovaskular (Tuba, 2014). Menurut Kodl and Seaquist, DM tipe 2 berhubungan dengan penurunan kecepatan psikomotor, gangguan lobus frontal/ fungsi eksekutif, verbal memory, working memory, immediate recall, delayed recall, verbal fluency dan atensi. Namun bagaimana mekanisme pasti masih belum jelas (Kodl dkk, 2008).

\section{SIMPULAN}

Pada penelitian ini didapatkan $66,1 \%$ pasien DM tipe 2 dengan gangguan kognitif, dan tidak ditemukan hubungan yang bermakna antara umur, jenis kelamin, tingkat pendidikan dan lama menderita DM tipe 2 dengan fungsi kognitif.

\section{REFERENSI}

Daniel L. 2015. The Impact of age on cognition. Pubmed Central Journal. 36(3):111-121.

Duron,E;Hanon,O.2008.Vascular Risk Faktors, Cognitive Decline, and Dementia. Vascular Health and Risk Management:4(2) 363-381.

Dongwha S. 2018. Sex differences in cognitive decline in subjects with high likelihood of mild cognitive impairment due to Alzheimer Disease. Scientific Report. 8:7490.

Ferrari C. 2018. Alzheimer disease progression: Faktors influencing cognitive decline. Journal of Alzheimer Disease. 61: 785-791.

Flatz.A .,Casillas.A.,Stringhini S., Zuercher E., Burnand B., Peytremann.I., Bridevaux. 2015. Association between education and quality of diabetes care in Switzerland. International Journal of General Medicine 2015:8 87-92.

Kasper DL, Fauci AS, Hauser SL, Longo DL, Jameson JL, Loscalzo J. Harrisons principles of internal medicine. 19th ed. New York: McGraw Hill Education; 2015 p2404-2407

Kodl, C. T., \& Seaquist, E. R. (2008). Cognitive dysfunction and diabetes mellitus. Endocrine reviews, 29(4), 494-511. doi:10.1210/er.2007-0034.

Ramli Y. 2017. Mild Cognitive Impairment. Buku Ajar Neurologi I. Fakultas Kedokteran Universitas Indonesia. 195-221

Shah A, Langenberg C, Rapsomaniki E, Denaxas S, Pujades-Rodriguez $\mathrm{M}$, Gale $\mathrm{C}$ et al. Type 2 diabetes and incidence of cardiovascular diseases: a cohort study in 1.9 million people. The Lancet Diabetes \& Endocrinology. 2015;3(2):105-113

Tuba Özcan., Esra Yancar Demir.2014. Investigation the Cognitive Impairment in Diabetes Mellitus Type 2 with Moca Test. J Psychiatry, 17:6

Unwin N. IDF diabetes atlas. Brussels: International Diabetes Federation; 2011 